\title{
The Analysis of Corporate Development from the Perspective of Corporate Culture --- With Some Case Analysis
}

\author{
Qi Zhao ${ }^{1}$ \\ ${ }^{1}$ Guangdong University of Foreign Studies, Guangzhou, China \\ Correspondence: Qi Zhao, Postgraduate student, Guangdong University of Foreign Studies, Guangzhou, China.
}

Received: August 10, 2016

Accepted: August 27, 2016

Online Published: August 30, 2016

doi:10.5430/ijba.v7n5p73

URL: http://dx.doi.org/10.5430/ijba.v7n5p73

\begin{abstract}
In this modern social enterprise, corporate culture is very important. The cultural factors have heavily affected the outcome of a company. Companies always struggle with different traditions and values, with problems arising when business is conducted. There are more famous enterprises in the world more than we can count. Each successful enterprise has its own unique corporate cultures. We even can say that some enterprises' success should be attributed to the corporate culture. Each corporate culture has differences and similarities. We can use it for reference, we can study it, we can copy it, but we can not do without it. We must construct corporate culture which should suitable for our own company. Corporate culture is the top priority, the soul of an enterprise, and the successful leading line.

In this thesis, we will talk about corporate culture and the relationship between corporate culture and enterprise development. The research examines the relationship that exists between the corporate cultures and the performance within a business environment. The purpose of this paper is to examine if there is a relationship between the interdependence among different components of corporate culture and its performance. The originality of the paper comes from combining corporate culture with types of organizational structures. The more we know more about the corporate culture and its performance, the better in the real business. Three cases will be discussed in this research. They would be the most suitable examples to show us the importance of corporate culture for enterprise development.
\end{abstract}

Keywords: corporate culture, enterprise development, case study

\section{Literature Review}

Culture is viewed from different perspectives. I shall try to focus my research on corporate culture compared with the culture in general.

\subsection{Definition of Culture}

Historically, the word 'culture' derives from the Latin word 'cultura', which could be interpreted into many meanings: land cultivating, fostering, sacrificing, spiritual edification, etc. In summary, culture refers to the creativity of human being. In China, it is generally considered that the word 'culture' emerges along with The Book of Changes, which tells us 'someone is different from others because of culture polish'. It is thus clear that the basic implication of culture is education and enlightenment.

However, there is no universally agreed definition. In Iris Varner and Linda Beamer's (2006) recent book Intercultural Communication in the Global Workplace, there shows a relatively accurate and wide used definition. "Culture is the coherent, learned, shared view of a group of people about life concerns that ranks what is important, furnishes attitudes toward things being appropriate and dictates behavior."

\subsection{Definition of Corporate Culture}

As a technical term, 'corporate culture' dates back to the western management circle in 1980s and it is also called 'organizational culture', enterprise culture, firm culture and company culture. Chinese scholar Wang Shuinen (2009) defined 'organization culture' from a broad scope in which 'organization' includes government, enterprises and other institutions. Corporate culture, however, refers to the culture of organizations in the business circle.

There is no recognized definition on 'corporate culture' just as there is no on 'culture'. Since corporate culture was put forward, scholars and researchers have been engaging in the discussion of it, and various definitions were 
brought out depending on different perspective of their own studies.

Professor Edgar H.Schein from MIT published his famous work entitled Organizational Culture and Leadership (2004) in which he gave a systematic description on corporate culture. In his work, corporate culture was defined as a series of assumptions from different dimensions, and he studied three levels of culture: artifacts which are hard to decipher, espoused values, and basic underlying assumptions which was ultimate source of values and actions. Various definitions from other scholars will be elaborated in the later discussion.

In spite of various kinds of definition on 'corporate culture', the essence of corporate culture remains the same. To summarize, corporate culture is studied both from a broad and narrow sense. The board one refers to the combination of a company's material, behavioral, institutional and spiritual culture, while the narrow one means a company's ideology focusing on corporate values. And the former will be applied in this paper's analysis so as to give a comprehensive and general study on the corporate culture.

\section{Studies on Corporate Culture}

\subsection{Emergence of Corporate Culture}

The rise of corporate culture was in 1980s. Since then the corporate culture theory is formed during its innovation on the existed management theories. It provides a new angle to interpret corporation's operation, putting the connection between management and culture onto the top priority. Four great works on corporate culture commenced a new chapter in this field.

The first contribution is the Theory Z: How American Business Can Meet the Japanese Challenge, written in 1981 by William G.Ouchi, an American management professor, held the argument that the core of management relied on staff's concern on the company. Ouchi analyzed a series of American-style and Japanese-style companies and put forward his 'Z-style' corporate mode and ' $Z$ Culture', which includes corporate values like forward-looking, flexibility and perseverance. ' $Z$ theory' had revealed the interrelationship of management and culture, and made a preparation for the development of corporate theory.

In 1981, the second one came out. Two American experts named Pascale.R.J and Athos A.G pointed out in their work The Art of Japanese Management that corporations which would like to succeed should not overlook seven changeable elements, namely, strategy, structure, systems, staffs, skills, styles, super-old integrals, which referred to the values followed by companies and its members. This theory is also called 'McKinsey $7 \mathrm{~S}$ frame' since ' $\mathrm{s}$ ' being in all initials of these seven elements and the theory is improved and popularized by experts in McKinsey.

In early 1980s, Terrence E.Deal, Harvard professor and Allan Kennedy, McKinsey consultant, published their book Corporate Cultures: the Rites and Rituals of Corporate Life after six months' detailed analysis on 80 companies. In this book, corporate culture is considered as five factors: cultural environment, values, hero, rites and ritual, as well as culture network, in which values are the most important. The book also analyze corporate culture, which indicates keeping eyes on company's unconsciousness from surface to inner side in a managerial consulting way.

The third contribution came from Deal\&Kennedy.Based on their research, they classified various corporate cultures into four types, that is, tough-guy macho culture, work-hard-play-hard culture, bet-your-company culture, and process culture. The classification was made based on two dimensions: how quickly organizations receive feedback on the success of management decisions or strategies; and the level of risks that they take. Besides, representative industries of each culture were also discussed, therefore, this classification was also made from an industry perspective to some extent.

Later, through their study on three companies in America, Tomas Peters and Robert Waterman wrote eight features of excellent American companies in their work. In Search of Excellence: Lessons from America's Best-run Companies. These excellent features form a distinctive type of corporate culture in one company.

To make a conclusion, these four publications mark the coming of corporate culture theory time. They are all based on Japanese corporate culture and explore a more effective management form in American companies. Besides, these works had brought corporate culture theory to all over the world and laid a solid foundation for the following studies. And among the four theories, Deal and Kennedy's five-element model is a general one involving company's inside and outside environments so it can be applied to analyze most company's situation, while the other two theories focus on the comparison between Japan and American management and another one's eight features can be contained into the five-element model. Therefore, Deal and Kennedy's five-element model combined with Hofstede's five-cultural dimension theory can be applied to conduct a study on Chinese multinationals' corporate culture construction. 


\subsection{Development of Corporate Culture}

With the popularization of corporate culture, business organizations have paid increasing attention to the significance of it during 1990s, and they tried to build a positive corporate image on the basis of corporate culture. Hence, emphasis on corporate culture was transferred from theoretical studies in 1980s to applied research and quantitative methods. There were four main directions as follows.

First of all, further studies on corporate culture theories. In the background of fiercer competition among western companies, theoretical studies focused on exploring how corporate culture differs during the managerial process. Important studies including Benjamin Scheider's Organizational Climate and Culture in 1990, Hofstede's further study stretched his five-dimensions of national culture into organizational culture.

Second, attention to measurement of corporate culture. In 1991, JAI Publishing from UK published five papers on corporate culture .In 1997, Pierre DuBois and Associates Inc. published their work named Organizational Culture Measurement and Optimization, including models applied to organizational analysis and culture research process.

Third, studies on connections between corporate culture and company performance. Outstanding works in this field includes a paper by Kim S.Cameron and Sarah J.Freeman (1991) from University of Michigan named Culture Congruence, Strength and Type: Relationships of Effectiveness, R.K.Divedi's Organization Culture \& Performance in 1995, and Daniel R.Denison's Corporate Culture \& Organizational Effectiveness in 1997. The most famous one is Harvard Professor John Kotter \& James Heskitt's work Organizational Culture and Performance in 1992, which proved corporate culture's critical influence on company's long-term performance and predicted corporate culture as the key factor of a company's rise and fall in the next ten years.

Fourth, studies on the diagnosis and evaluation of corporate culture. Works include Roger Harrison \& Herb Stokes's (1992) named Diagnosing Organizational Culture:Instrument and Trainers Manual, Kim S.Cameron \& Robert E.Quinn's (1998) Diagnosing and Changing Organizational Culture: Based on the Competing Values Framework. Even though works on culture evaluation was not published officially yet, discussions about it were taken in various forums (Wang, 2009).

\subsection{Corporate Culture Construction}

There are few specific definitions on corporate culture construction. In his book Corporate Culture Construction: from Culture Construction to Cultural Management, Wang Jipeng (2010) regarded 'culture construction' as a process of corporate culture's formation, building and spreading. The focus of corporate culture construction is on 'construction' which means building and forming.

According to scholar Wang Shuinen's (2009) works, corporate culture construction is a series of actions and steps taken by companies with a clear objective and specific plans. More specifically, it is a systematic measure abstracted from a company's actual situation which should be applicable and executable inside the organization. The process will help contribute to a common values system generally recognized by its people who will stick to a consistent standard and principles followed by all the corporate members. On the other hand, corporate culture should coincide with the culture of social public as well as targeted market, through showing positive image and remaining a harmonious relationship with the society. Here, it is worth mentioning that the difference between the so-called 'cultural management' and 'culture construction'. According to Wang Jipeng's (2004) study, cultural management refers to corporate culture's integration, planting and promotion. It pays more attention to the importance of 'management'. It is a cycling and spiraling process, and it concentrates on 'how to put ideology into action' while culture construction focuses more on 'how to form the ideology'. Cultural management is a broader scope which involves culture construction, culture planting, culture evaluation and culture re-creation. In addition, it is inevitable for a company to enter the cultural management period from the culture construction period and the latter is just the founding stage of the former.

Corporate culture construction is a systematic process, and its objectives should go in line with and modify with company's situation and strategic goals. Generally speaking, objectives of corporate culture construction can be divided into two aspects: to build a company's soul internally so as to improve its competitiveness, and to create an attractive outside image so as to increase company's intangible assets. The latter is also discussed combining with CI design and social responsibility, and this paper will focus on the internal force of corporate culture (Deal\&Kennedy, 2008).

Domestic scholar Wang Shuinen (2009) contributes to defining specific subjects of the process. According to his study, subjects include company leader, a specific culture-construction team, company's culture department, middle managers, company employees and experts from outside the company. Then he gave a short introduction about each 
subject's role and assignment during the culture construction process in which leader served as a designer and fugue man, the particular group was responsible for executing the whole process, and expert instructions was of great importance to the final result.

\section{Case Analysis}

\subsection{IBM's Corporate Culture}

International Business Machines Corporation, or IBM, was founded in 1911 as the Computing Tabulating Recording Company (CTR) through merger of three companies, and CTR adopted the name International Business Machines in 1924. Its distinctive culture and product branding has given it the nickname 'Big Blue'. The IBM Personal Computer, commonly known as the IBM PC, is the original version and progenitor of the IBM PC compatible hardware platform. It was introduced in 1981 and turned out to be a great success.

In spite of its great success today, IBM has experienced ups and downs for several times. In September 1993, Louis Gerstner, IBM's new Chairman and CEO, drafted eight principles as the ideology of new IBM's culture. The eight principles integrated excellent parts of the original culture while correcting the conservative philosophy of the old IBM. Some of the principles are concluded as follows:

The first is market-orientation or customer-orientation. The company realized the importance of customer-orientation instead of self-orientation. In addition, the new culture takes customer satisfaction and shareholder values as the first criteria leading the company's actions. IBM regards meeting customer demand as the paramount task and makes its every effort to serve customers well.

Second, people respect, which is widely recognized but rarely done. Successive leaders in IBM are deeply aware of the significance of people. Employees are encouraged to develop themselves and to compete with their managers in performance.

Third, re-emphasize the positioning of being a technological company equipped with high quality. The most important task of the company is transforming technology into products and eventually meeting customer demands.

Fourth, stay innovative and focusing on productivity instead of bureaucracy. IBM needs to make consistent progress through expanding its old business and exploring new business. The values of unceasing innovation need to guide the company to take risks and pursue improvements through immediate actions.

\subsection{Microsoft Corporation Culture}

The word, Microsoft, is known by everyone who used computer. In 1975, Paul Allen and Bill Gates founded Microsoft Corporation. To face the challenges of market and technology, Microsoft has always followed the most basic strategy----march to the future. It has an excellent president and senior management team, and the extraordinary talents of employees. Microsoft people have the spirit of learning to improve and daring to deny themselves. Through the brilliant achievements, we can easily find their success lies not only in technological innovation and excellent management, but more important in the creation of a knowledge-based enterprises unique cultural personality.

The core content in knowledge economy is innovation. Innovation should be the essence of knowledge-based corporate culture. Microsoft people have always been a pioneer. Microsoft's ongoing incremental product innovation, created a continuous metabolic mechanism which makes its competitors have the few opportunities to be able to pose a threat to Microsoft. Innovation is the core spirit of the whole business in the process of Microsoft's management.

By e-mail to establish extensive contacts and trust, Gates and other executives urged that people keep in close contact, to enhance interactive learning, share resources. The establishment of learning organization makes the company integrates be more close and march to the future.

\subsection{Haier Corporation}

Haier is a brilliant company with strong corporate culture. Haier corporate culture has been widely recognized by Haier's employees as innovative value created by Haier senior management.

Innovation is the core of Haier corporate culture, Haier's unique cultural system cultivated and developed over the past 20 years. Haier corporate culture is guided and developed by advanced concept, innovative strategy, efficient organization, creative technology and market orientation, which have enabled Haier to grow swiftly with business expansion from China to outside world. Haier spirit Creating resources and worldwide prestige Resource Creation is based on innovation. Even Haier has less resources than its competitors, it can benefit from the core competence originated from innovation. 
The higher objective of the Global Brand strategic stage is 'worldwide prestige' which is accomplished in meeting the needs of customers from all over the world and which will in turn make Haier a globally recognized world-class brand.

Haier provides its every employee opportunities to develop and demonstrate talents. The responsibility of a manager is to establish a 'race track', i.e. personality development opportunity, for every employee to become a SBU.

Reputation is more important than sales volume Quality is the essence of a product, so as reputation to a business. A product should be deemed as acceptable only when it satisfies the customer very well. Build good impression to build good impression is to be fully devoted to work, spare no efforts to satisfied personalized needs and care for work and customer. As concluded by an expert from Rand, a famed consultancy, Haier in its course of internationalization will certainly initiate a bright future with an impressive, cohesive and innovative brand image.Core competence is the outstanding ability to obtain customer and user resources. The core competence doesn't lie in any single element. It is about acquiring customer resources and customer loyalty that make you competitive in market. Why is Haier warmly received in the United States? The reason lies in the customer need identification.

\section{Conclusion}

To sum up, corporate culture is becoming more and more popular among the managers. They believe that an outstanding corporation should have its own corporate culture that will strengthen the internal control. However, whether a corporation should impose corporate culture wherever they operate and how strong the corporate culture should be are controversial issue. In previous paragraphs, advantages of corporate culture and factors that may vary the effectiveness of corporate culture have been discussed to argue that corporate culture could be applied as an efficient 'informal management tool', but it should be more careful to consider whether corporate culture is positive in different kinds of organizations, in terms of organizational structure, level of employees' commitment. We should conduct more detailed studies about corporate culture.

\section{References}

Chung, K. H., Lubatkin, M. H., Rogers, R. C., \& Owers, J. E. (1987, November). Do insiders make better CEOs than outsiders? Academy of Management Executive, 325-331.

Davidson, W. N., Worrell, D. L., \& Cheng, L. (1990). Key executive succession and stockholder wealth: The influence of successor's origin, position, and age. Journal of Management, 16(3), 647-664.

Deal, T. E., \& Kennedy, A. A. (1982). Corporate Cultures: the Rites and Rituals of Corporate Life. Addison-Wesley, MA., p.21.

Hall, E. T. (1959). The Silent Language. New York: Anchor Press Doubleday.

Hall, E. T. (1976). Beyond Culture. New York: Anchor Press Doubleday.

Hofstede, G. H. (1980). Culture's Consequence: International Differences in Work-related Values. Beverly Hills CA: Sage.

Hofstede, G. H. (1984). Cultural Dimensions in Management and Planning. Asia Pacific Journal of Management, 1(2).

Hofstede, G. H. (1991). Cultures and Organizations: Software of the Mind. London, McGraw-Hill, p.53.

Kluckhohn, F.R., \& Strodtbeck, F. L. (1961). Variations in Value Orientations. Evanston: Row, Peterson \& Co.

Larcon, J.-P., \& Zhao, C. (2009). Chinese Multinationals. China Machine Press.

Pascale, R. T., Athos, A. G., \& Simon, S. (1981). The Art of Japanese.

Sylvie. (2003). Cross-cultural Management in Multinational Project Groups. Journal of World Business, 38. 